\title{
RESEARCH PAPER \\ Effects of the foliar application of methanol on the yield and growth of rice (Oryza sativa cv. Shiroudi)
}

\author{
Abouzar Abbasian ${ }^{1}$, Bahram Mirshekari ${ }^{1}$, Mohammad N. Safarzade \\ Vishekaei $^{2}$, Varahram Rashidi ${ }^{1}$, and Hashem Aminpanah ${ }^{2}$ \\ 'Department of Agronomy and Plant Breeding, Tabriz Branch, Islamic Azad University, Tabriz, Iran. \\ ${ }^{2}$ Department of Agronomy and Plant Breeding, Rasht Branch, Islamic Azad University, Rasht, Iran.
}

\begin{abstract}
A. Abbasian, B. Mirshekari, M.N. Safarzade Vishekaei, V. Rashidi, and H. Aminpanah. 2016. Effects of the foliar application of methanol on the yield and growth of rice (Oryza sativa cv. Shiroudi). Cien. Inv. Agr. 43(1):17-24. Approximately two decades have passed since it was reported that the foliar application of methanol increased plant biomass and yield. Many subsequent reports have been published concerning the ability or inability to reproduce these initial observations. To evaluate the effect of methanol on rice (Oryza sativa cv. Shiroudi) yield and rice components, a field experiment was conducted at the Tonekabon Rice Research Station in Iran in 2012 and 2013. The experiment had a randomized complete block design (RCBD) with three replicates. The plants were treated with aqueous methanol solutions $(0$, $6,12,18$, and $24 \%(\mathrm{v} / \mathrm{v}))$. Methanol was sprayed on the rice foliage three times during the experimental period at two-week intervals. The results indicated that, in general, the methanol did not affect rice growth or yield and seemed to be ineffective as a growth enhancer, so foliar spraying of aqueous methanol cannot be recommended for rice. The negative results could be due to the absence of Methylobacterium sp. or that the effects are cultivar-specific because positive effects on the growth and yield of rice have been reported in other cultivars.
\end{abstract}

Key words: Aqueous methanol solution, correlation, glycine, grain yield, growth, rice, Tween 80 as a surfactant.

\section{Introduction}

Rice (Oryza sativa L.) is one of the most important cereal food crops (Eckardt, 2000). Global population estimates have predicted the need for a $70 \%$ increase in rice production over the next 30 years (Lee et al., 2006) to provide a staple food for more than half of the world's population (Sasaki and Burr, 2000). Due to the constant increase of the

Received July 15, 2015. Accepted January 28, 2016. Corresponding author: mirshekari@iaut.ac.ir world's population and adverse climatic conditions, the increase in the rate of rice production adequate to satisfy the increased demand for food should be approximately $1 \%$ per year (Sass et al., 2002). Rice is a principal food in Iranian cuisine, and the quality of cooked rice outweighs all other considerations among Iranian consumers. The total area under rice cultivation in Iran is more than 600,000 hectares and rice is grown in 15 provinces. The consumption of rice in Iran has been estimated at $28 \mathrm{~kg}$ per capita per year. As the supply and demand for rice in Iran are not 
yet evenly balanced, Iran imports approximately 400,000 to 500,000 tons of rice for domestic consumption (Pourimani and Anoosheh, 2015).

Numerous experiments have shown that an increase in the $\mathrm{CO}_{2}$ content of the air led to an increase in crop yields (Devlin et al., 1994), accelerated flowering (Fisher et al., 1997), and a greater accumulation of carbohydrates by plants (Abdel-Latif et al., 1996). Spraying methanol is a method which increases crop $\mathrm{CO}_{2}$ fixation in a given area. Recent investigation has shown that the yield and growth of $\mathrm{C}_{3}$ crops was increased via methanol spraying and that methanol may be a $\mathrm{C}$ source for these crops (Makhdum et al., 2002). In most cases, $25 \%$ of the carbon in $\mathrm{C}_{3}$ plants is used for photorespiration, and the amount of photorespiration can be minimized by the foliar application of methanol (Gout et al., 2000) because methanol is rapidly metabolized to $\mathrm{CO}_{2}$ and water in plant tissue (Safarzadeh Vishekaei et al., 2007). The foliar application of methanol indirectly stimulates the methyltrophic bacteria that live on most plant leaves. These bacteria consume some of the methanol on the leaves and induce plant growth via auxin and cytokine production (Ivanova et al., 2001).

A wide range of $\mathrm{C}_{3}$ crops and ornamental plants have shown an increase in growth and the yield of fruits or seeds after spraying with $10-50 \%$ methanol. Positive responses have been reported for wheat (Triticum aestivum L.), peas (Pisum sativum L.) (Devlin et al., 1994), oilseed rape (Brassica napus var. oleifera) (Karczmarczyk et al., 1995), geranium (Pelargonium sp.), and bachelor's button (Centaurea cyanus L.) (Devlin et al., 1995). However, some publications report no gain of biomass of treated plants (Hartz et al., 1994; Mauney and Gerik, 1994; McGiffen et al., 1995; Mitchell et al., 1994). Nonomura and Benson (1992) reported large increases in the growth and yield of a wide range of $\mathrm{C} 3$ species: tomato (Lycopersicon esculentum Mill.), 50\%; strawberry (Fragaria ananassa Duchesne), 60\%; eggplant (Solanum melongena L.), 60\%; cotton (Gossypium hirsutum L.), 50\%; savoy cabbage (Brassica oleracea L. Capitata Group), 50\%; wheat (Triticum aestivum L.), 100\%; rose (Rosa spp.), 40\%; palm (Washingtonia robusta $\mathrm{H}$. Wendl.), 70\%; and watermelon [Citrullus lanatus (Thunb.) Matsum \& Nakai], 36\%. Li et al. (1995) reported that methanol had a positive effect of the seed yield, seed weight, and the number of pods per plant of soybeans. Safarzadeh Vishekaei et al. (2007) found that the foliar application of 20\% methanol increased the leaf area index, the crop growth rate, the pod growth rate, the radiation use efficiency, the pod and grain yield, the 1000 grain weight, the number of ripened pods, and the grain protein concentration in peanuts. Nadali et al. (2010) demonstrated that the application of $21 \%(\mathrm{v} / \mathrm{v})$ methanol had the greatest impact on the root yield, leaf weight, and yield of sugar beets. In addition to increasing the yield, some crops showed reduced photorespiration along with an increased cell turgor in plant tissue and an enhanced capacity for photosynthesis during the reproductive stage due to an increase of $\mathrm{CO}_{2}$ (Nonomura and Benson, 1992). Armand et al. (2016) reported that treatment with 20\% methanol in beans (Phaseolus vulgaris L.) at the seedling stage resulted in increased net photosynthesis $\left(P_{\mathrm{N}}\right)$, intercellular $\mathrm{CO}_{2}$ concentration $\left(C_{\mathrm{i}}\right)$, and a decreased transpiration rate under non-stress conditions.

Understanding the impact of methanol on plants is still controversial because different studies on its impact on photosynthetic activity and biomass production in plants have produced different results (Zheng et al., 2008). Some studies have suggested that both biomass production and photosynthetic activity in algae were increased at low methanol concentrations (Theodoridou et al., 2002). Changes in photosynthetic metabolism due to a change in environmental conditions or agricultural practices lead to a change in plant's growth and productivity (Pallardy, 2010), while foliar applications of methanol increased $\mathrm{CO}_{2}$ assimilation in plants (Ganjeali, 2012). There are few studies on methanol in Iran. Rice is a very 
valuable economic product and an important food source that is consumed daily worldwide, but a water deficit is a problem for rice cultivation in Iran. The main objectives of our experiments were to (1) assess whether methanol enhances the growth and yield of rice and (2) determine the efficacious methanol concentration for foliar application.

\section{Materials and methods}

\section{Growing Conditions}

These experiments were conducted at the experimental farm of the Tonekabon Rice Research Station $\left(36^{\circ} 51^{\prime} \mathrm{N}, 50^{\circ} 46^{\prime} \mathrm{E}\right.$; $-20 \mathrm{~m}$ above sea level) in the north of Iran during April - August of 2012 and 2013. The soil at the experimental site was a Silty clay loam, with $3.2 \%$ organic matter, $30 \%$ clay, $50 \%$ silt, $20 \%$ sand, a $\mathrm{pH}$ of 7.61, a cation exchange capacity (CEC) of 29.9 meg 100 g, $0.338 \%$ total soil nitrogen, $3.25 \%$ organic carbon, $13.6 \mathrm{mg} \mathrm{kg}^{-1}$ of phosphorus, and $88 \mathrm{mg} \mathrm{kg}^{-1}$ available potassium. To simplify the comparison of the growing season weather, we considered the monthly total precipitation and temperature from May through August at the Tonekabon Rice Research Institute (Table 1).

Rice seeds were disinfected with $70 \%$ thiophanatemethyl WP (Melli Agrochemical Company (PAC);

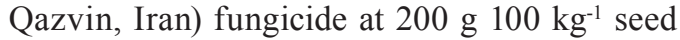
and were then sown in the nursery. The seedlings were manually transplanted in the experimental field at the 2-3 leaf stage at a spacing of $25 \times 25$ $\mathrm{cm}^{2}$. Recommended rates of nitrogen $(100 \mathrm{~kg}$ $\left.\mathrm{ha}^{-1}\right)$, phosphorous (100 kg ha-1), and potassium $\left(150 \mathrm{~kg} \mathrm{ha}^{-1}\right)$ were applied. One-third amount of the nitrogen and all of the phosphorous and potassium were applied as a basal dose at the transplant stage. The remaining two-thirds of the nitrogen were applied in two split doses 30 days after transplanting (at the tiller stage) and at the panicle initiation stage. Weeds were controlled by hand weeding during the growth season. The permanent flood water level was maintained at $10 \mathrm{~cm}$ during the rice growing period.

\section{Methanol application}

Methanol was sprayed on the rice foliage three times at two week intervals. The first foliar application was 45 days after transplanting on June 30th, and the second and third applications were on the 13th and the 27th of July, between 1600 to 1900 hours on bright, hot sunny days. Cossins (1964) reported that methanol was utilized and converted to sugars and amino acids when applied to plant tissue during darkness. The methanol was sprayed so all of the above ground parts of the rice plants were covered. A back engine sprayer with a 20 L capacity was used to spray, and the sprinkler was positioned

Table 1. Monthly precipitation and temperature from May to September for the growing season (2012-2013) at the Tonekabon Rice Research Institute, Iran.

\begin{tabular}{lccccc}
\hline & & & \multicolumn{3}{c}{ Temperature $\left({ }^{\circ} \mathrm{C}\right)$} \\
\cline { 3 - 5 } Month & Year & Precipitation $(\mathrm{mm})$ & Maximum & Minimum & Average \\
\hline May & 2012 & 28.3 & 25.29 & 18.45 & 21.87 \\
June & 2012 & 117.9 & 28.38 & 21.23 & 24.81 \\
July & 2012 & 125 & 29.12 & 22.81 & 25.96 \\
August & 2012 & 86.5 & 30.9 & 24.22 & 27.56 \\
& & & & \\
May & 2013 & 26.3 & 23.3 & 16.1 & 19.7 \\
June & 2013 & 14.3 & 27.7 & 20.7 & 24.2 \\
July & 2013 & 70.1 & 29.5 & 23.1 & 26.3 \\
August & 2013 & 27.1 & 28.4 & 22.2 & 25.3 \\
\hline
\end{tabular}


at $40 \mathrm{~cm}$ above the plants. The methanol (Merck Company, Darmstadt, Germany) solutions also included 0.1\% Tween 80 (v/v) (J.T. Baker Chemical Company, Phillipsburg, New Jersey) as a surfactant. Glycine apparently increased the rate of methanol metabolism. Glycine was added to the sprayed solution to prevent injury from high methanol concentrations or when the light intensity was low (Nonomura and Benson, 1992). The addition of up to $2 \mathrm{~g} \mathrm{~L}^{-1}$ glycine to the methanol solution enabled the use of higher methanol concentrations without visible injury.

At maturity, the plant height (from the soil surface to the top of the plant canopy) and the tiller number were measured. The plants were harvested by hand-cutting at the soil surface and subsequently, the aboveground biomass of the rice was determined. The rice aboveground biomass from each plot was placed in a separate paper bag, dried at $72^{\circ} \mathrm{C}$ for $48 \mathrm{~h}$, and weighed. The yield components included the tiller number, and the 1000- grain weight was measured according to the standard evaluation system. Plants were harvested at 107 days after transplanting. The plots were hand harvested for rough rice yields at $2.5 \mathrm{~m}^{2}$ and adjusted to $14 \%$ moisture.

\section{Statistical analysis}

The experimental design was a randomized complete block with three replicates and five treatments: $0,6,12,18$, and $24 \%(\mathrm{v} / \mathrm{v})$ methanol. The statistical analysis was conducted using the SAS software (SAS Institute Inc. Cary, USA) (SAS Inst., 1990) to determine whether the effects of the application of methanol was significantly different between treatments. Means were compared using Fisher's protected LSD test at $\alpha=0.05$. A correlation analysis was used to draw inferences about the relationship between the agronomic traits under consideration using the PASW Ver. 18.0 statistical software (SPSS Inc., Hong Kong).

\section{Results and discussion}

An analysis of variance showed that methanol treatments had no significant effect on any trait at the $5 \%$ probability level (Table 2). For both years (2012 and 2013), the rice grain yield was not significantly increased following methanol foliar application. On the contrary, Nonomura and Benson (1992) reported that the plant growth rate was significantly increased in response to the foliar application of methanol. Furthermore in our study, no differences in the biological yield, harvest index (HI), plant height, tiller number, or unfilled grain number (Table 3) were evident. The highest 1000 -grain weight was observed in the methanol treatments in comparison with control treatment. Additionally, the highest filled grain number occurred in the control treatment. A correlation analysis provides a good indication of the association between growth parameters and helps to identify the most important growth parameter(s) to be considered for the effective selection for a higher yield. The correlation analysis (Table 4) showed a significant positive correlation between the rice yield and the biological yield $(\mathrm{P} \leq 0.01$, $0.75)$, plant height $(P \leq 0.01,0.64)$, and the tiller number $(\mathrm{P} \leq 0.05,0.36)$.

In our study, the quantities of methanol applied to the plants were so small compared to carbon fixation in the plant canopy during the growing season that changes in growth could not be expected to result from the alcohol application. Moreover, the extent of the methanol absorption and utilization in the plant it is not clear. Cossins (1964) observed a large variation in the utilization of methanol when it was fed to different cell tissues of various crop species. The methanol may not have affected the rice because of the rainy weather during the rice growth period (Table 1) because the effect of methanol is greater during a water shortage and stress conditions (Safarzadeh Vishekaei et al., 2007). 
Table 2. Analysis of variance of the effects of methanol application on the growth and yield of rice.

\begin{tabular}{|c|c|c|c|c|c|c|c|c|c|}
\hline \multirow[b]{2}{*}{ SOV* } & \multirow[b]{2}{*}{$\mathrm{df}$} & \multicolumn{8}{|c|}{ Mean squares } \\
\hline & & Grain yield & $\begin{array}{l}\text { Biological } \\
\text { yield }\end{array}$ & $\mathrm{HI}$ & $\begin{array}{l}\text { Plant } \\
\text { height }\end{array}$ & $\begin{array}{c}\text { Tiller } \\
\text { number }\end{array}$ & $\begin{array}{c}1000 \text { - grain } \\
\text { weight }\end{array}$ & $\begin{array}{l}\text { Number of } \\
\text { filled grain }\end{array}$ & $\begin{array}{l}\text { Number of } \\
\text { unfilled grain }\end{array}$ \\
\hline Year (Y) & 1 & $8815.9 \mathrm{~ns}$ & $1306887.8 \mathrm{~ns}$ & $34.59 *$ & $54.41 \mathrm{~ns}$ & 5.57 & $4.33^{*}$ & $469.26^{*}$ & $963.9^{* *}$ \\
\hline Rep. & 2 & 427546.5 & 488038.5 & 2.40 & 5.9 & $7.49 \mathrm{~ns}$ & 0.096 & 217.21 & 13.84 \\
\hline Methanol (M) & 4 & $507927.7 \mathrm{~ns}$ & $1439270.6 \mathrm{~ns}$ & $8.87 \mathrm{~ns}$ & $17.26 \mathrm{~ns}$ & $3.08 \mathrm{~ns}$ & $1.04 \mathrm{~ns}$ & $153.67 \mathrm{~ns}$ & $4.81 \mathrm{~ns}$ \\
\hline $\mathrm{M} \times \mathrm{Y}$ & 4 & $725133.7 \mathrm{~ns}$ & $1875692.8 \mathrm{~ns}$ & $1.25 \mathrm{~ns}$ & $3.82 \mathrm{~ns}$ & $4.98 \mathrm{~ns}$ & $0.7 \mathrm{~ns}$ & $36.82 \mathrm{~ns}$ & $14.49 \mathrm{~ns}$ \\
\hline Error & 18 & 851951.8 & 2638856.6 & 7.26 & 29.32 & 4.54 & 0.38 & 73.1 & 19.79 \\
\hline CV (\%) & & 13.34 & 14.19 & 5.05 & 5.3 & 10.51 & 2.26 & 7.85 & 25.05 \\
\hline
\end{tabular}

*Sources of variation.

ns $=$ non-significant; $* * *$ significant at the $5 \%$ and $1 \%$ probability levels, respectively.

Table 3. Comparison of the means of the growth parameters of rice as affected by methanol treatment.

\begin{tabular}{lcccccc}
\hline & \multicolumn{7}{c}{ Treatments $(\%$ alcohol $(\mathrm{v} / \mathrm{v}))$} & LSD $_{0.05}$ \\
\cline { 2 - 6 } Ingredients & 0 & 6 & 12 & 18 & 24 & 1119.6 \\
\hline Grain yield $\left(\mathrm{kg} \mathrm{ha}^{-1}\right)$ & $7024.6 \mathrm{a}$ & $7168.3 \mathrm{a}$ & $6928.1 \mathrm{a}$ & $7051.8 \mathrm{a}$ & $6421.4 \mathrm{a}$ & 1970.4 \\
Biological yield $\left(\mathrm{kg} \mathrm{ha}^{-1}\right)$ & $7024.6 \mathrm{a}$ & $11341.6 \mathrm{a}$ & $11811.9 \mathrm{a}$ & $11861.4 \mathrm{a}$ & $10651.5 \mathrm{a}$ & 5.27 \\
HI (\%) & $51.67 \mathrm{a}$ & $54.65 \mathrm{a}$ & $54.32 \mathrm{a}$ & $53.55 \mathrm{a}$ & $52.65 \mathrm{a}$ & 3.27 \\
Plant height (cm) & $103.37 \mathrm{a}$ & $101.2 \mathrm{a}$ & $103.47 \mathrm{a}$ & $102.95 \mathrm{a}$ & $99.55 \mathrm{a}$ & 6.57 \\
Tiller number & $20.8 \mathrm{a}$ & $20.57 \mathrm{a}$ & $20.67 \mathrm{a}$ & $20.29 \mathrm{a}$ & $19.03 \mathrm{a}$ & 2.58 \\
1000 - grain weight (g) & $26.83 \mathrm{~b}$ & $27.25 \mathrm{ab}$ & $27.63 \mathrm{a}$ & $27.93 \mathrm{a}$ & $27.28 \mathrm{ab}$ & 0.75 \\
Number of filled grain & $116.13 \mathrm{a}$ & $110.23 \mathrm{ab}$ & $107.3 \mathrm{ab}$ & $109.04 \mathrm{ab}$ & $102.13 \mathrm{~b}$ & 10.37 \\
Number of unfilled grain & $17.93 \mathrm{a}$ & $16.2 \mathrm{a}$ & $17.97 \mathrm{a}$ & $18.3 \mathrm{a}$ & $18.4 \mathrm{a}$ & 5.39 \\
\hline
\end{tabular}

Each value represents mean \pm S.E. of three replicates per treatment.

Under water stress conditions, methanol might function as an osmoprotectant, protecting the plant's vital processes and enabling a quick recovery when the stress is removed. Another possible explanation for the positive response to water stress conditions could be that methanol blocks the senescent effect of ethylene in stressed plants and therefore improves recovery (Safarzadeh Vishekaei et al., 2007). Further studies are being conducted to reveal more precisely the effect of methanol on stressed plants (Rajala et al., 1998). Nonomura and Benson (1992) reported that the foliar application of aqueous methanol increased the yield, accelerated the maturity, and reduced the drought stress and irrigation requirements in crops grown in an arid environment at high temperature in direct sunlight.

Rajala et al. (1998) did research on some of the $\mathrm{C}_{3}$ crops, including spring cereal (barley, wheat, and oats), peas, and summer turnip rape, and observed that methanol did not affect the growth and the yield of any of the crop species investigated and was therefore ineffective as a growth enhancer. They stated that the effect of methanol depends on a relatively low air temperature during the evening, which reduces the evaporation of methanol from the leaf surface and increases the possibility that methanol will penetrate into the plant. This is especially important at a high methanol concentration. Accordingly, it is likely that the plants transformed the methanol into other compounds in the field experiments, even though the methanol was not applied during a period of high light intensity. It is also likely that the methanol penetration into the plant is greater when applied at lower temperatures during the night. Wilson et al. (1996) applied aqueous methanol (6 concentrations from 0 to $50 \%$ ) on barley and found that none of the treatments significantly affected crop performance. Accord- 
Table 4. Correlation coefficients for the growth parameters of rice.

\begin{tabular}{|c|c|c|c|c|c|c|c|}
\hline Traits & Grain yield & $\begin{array}{l}\text { Biological } \\
\text { yield }\end{array}$ & $\mathrm{HI}$ & Plant height & $\begin{array}{c}\text { Tiller } \\
\text { number }\end{array}$ & $\begin{array}{c}1000 \text { - grain } \\
\text { weight }\end{array}$ & $\begin{array}{l}\text { Number of } \\
\text { filled grain }\end{array}$ \\
\hline Biological yield & $0.75 * *$ & 1 & & & & & \\
\hline $\mathrm{HI}$ & $-0.07 \mathrm{~ns}$ & $-0.12 \mathrm{~ns}$ & 1 & & & & \\
\hline Plant height & $0.64 * *$ & $0.65^{* *}$ & $-0.27 \mathrm{~ns}$ & 1 & & & \\
\hline Tiller number & $0.36^{*}$ & $0.33 \mathrm{~ns}$ & $-0.06 \mathrm{~ns}$ & $0.17 \mathrm{~ns}$ & 1 & & \\
\hline 1000 - grain weight & $0.02 \mathrm{~ns}$ & $-0.02 \mathrm{~ns}$ & $-0.13 n s$ & $0.13 \mathrm{~ns}$ & $-0.1 \mathrm{~ns}$ & 1 & \\
\hline Number of filled grain & $0.17 \mathrm{~ns}$ & $0.23 \mathrm{~ns}$ & $-0.12 n s$ & $0.39 *$ & $-0.16 n s$ & $0.06 \mathrm{~ns}$ & 1 \\
\hline Number of unfilled grain & $-0.12 \mathrm{~ns}$ & $-0.04 n s$ & $-0.45^{*}$ & $0.39 *$ & $-0.06 \mathrm{~ns}$ & $0.44 *$ & $0.22 \mathrm{~ns}$ \\
\hline
\end{tabular}

ns $=$ non-significant; $*, * *$ significant at the $5 \%$ and $1 \%$ levels of probability, respectively.

ing to Nonomura (personal communication), one application was sufficient to improve plant productivity, but multiple applications were required to achieve the maximum benefit. We followed Nonomura and Benson's treatment protocol, but we found that foliar methanol application did not effectively enhance any rice plant performance parameter under irrigated field conditions.

It could be useful to verify the presence of the methyltrophic bacteria in the plant tissues (leaves) because the absence of these bacteria could be another cause of the negative effect of methanol on the growth and yield of the rice. It has been shown that bacterial species of the genus Methylobacterium can help to consume some of the methanol on the leaves and induce plant growth via auxin and cytokine production for the best growth and yield of rice. We recommend a test to assess the presence or absence of these bacteria for a fuller explanation of our results.
In conclusion, this study indicated that methanol application did not seem to have a growth promoting effect on rice in the growing conditions in Iran. It seems that the rainy weather during the experimental period was responsible for the lack of an effect of the methanol on rice. It could be useful verify the presence of methyltrophic bacteria in the plant tissues (leaves) because the absence of these bacteria could be another cause of the negative effect of the methanol on the growth and yield of the rice. It has been shown that bacterial species of the genus Methylobacterium can help to consume some of the methanol on the leaves and induce plant growth via auxin and cytokine production for the best growth and yield of the rice cultivar Co-47 (Oryza sativa L.) (Madhatyan et al., 2004). We recommend a test to assess the presence or absence of these bacteria before and after of the application of methanol for a fuller explanation of our results.

\section{Resumen}

A. Abbasian, B. Mirshekari, M.N. Safarzade Vishekaei, V. Rashidi y H. Aminpanah. 2016. Efectos de la aplicación foliar de metanol en el rendimiento y el crecimiento de arroz (Oryza sativa cv. Shiroudi). Cien. Inv. Agr. 43(1):17-24. Hace aproximadamente dos décadas se informó que la aplicación foliar de metanol produce aumento de la biomasa y el rendimiento de las plantas. Desde entonces, muchos informes han sido publicados describiendo la capacidad o incapacidad de reproducir estas observaciones iniciales. Con el fin de evaluar el efecto de metanol en el arroz (Oryza sativa cv. Shiroudi) en el rendimiento y sus componentes, se desarrolló un experimento de campo en la Estación de Investigación del Arroz de Tonekabon, Irán, durante 2012 y 2013. El diseño estadístico usado fue de bloques completamente aleatorios (DBCA), con tres repeticiones. Los tratamientos estudiados fueron soluciones acuosas de metanol $(0,6,12,18$ y $24 \%(\mathrm{v} / \mathrm{v}))$. El metanol se pulverizó sobre partes de follaje de arroz tres 
veces durante su período de crecimiento, con intervalos de dos semanas. Los resultados de estos experimentos indicaron que, en general, el metanol no afectó el crecimiento y el rendimiento del arroz y, por lo tanto, parecía ser ineficaz como un promotor de crecimiento, en cambio, no se pueden recomendar pulverizaciones foliares de metanol acuoso para el arroz. Esto podría ser debido a la ausencia del Methylobacterium sp. o que el cultivar no ha sido adecuada, ya que otros cultivares de arroz se produce un efecto positivo en el crecimiento y rendimiento de arroz. Se otorgan mayores comentarios en las conclusiones finales del estudio.

Palabras clave: Arroz, correlación, crecimiento, glicina, rendimiento de grano, soluciones acuosas de metanol, Tween 80 como agente tensioactivo.

\section{References}

Abdel-Latif, A., U. Schmieden, S. Barakat, and A. Wild. 1996. Physiological and biochemical responses of sunflower plant to enhanced $\mathrm{CO}_{2}$ level. Plant Physiology and Biochemistry Special Issue 133:21-29.

Armand, N., H. Amiri, and A. Ismaili. 2016. The effect of methanol on photosynthetic parameters of bean (Phaseolus vulgaris L.) under water deficit. Photosynthetica 54 (In press).

Cossins, E.A. 1964. The utilization of carbon-1 compounds by plants. I. The metabolism of methanol $\mathrm{C}_{14}$ and its role in amino acids biosynthesis. Canadian Journal of Biochemistry 42: 1793-1802.

Devlin, R.M., P.C. Bhowmik, and S.J. Karczmarczyk. 1994. Influence of methanol on plant growth. Plant Growth Regulator Society of America 22(4): 102-108.

Devlin, R.M., S.L. Karczmarczyk, and P.R. Lopes. 1995. The effect of methanol on the growth and pigment content of bachelor's-button (Centaurea cyanus) and geranium (Pelargonium hortorum). Plant Growth Regulator Society of America 23: 127 -136.

Eckardt, N.A. 2000. Sequencing the rice genome. The Plant Cell 12: 2011-2018.

Fischer, B.U., M. Frehner, T. Hebeisen, S., Zanetti, F. Stadelmann, A. Lüscher, U.A. Hartwig G.R. Hendrey, H. Blum, and J. Nösberger. 1997. Source-sink relations in Lolium perenne L. as reflected by carbohydrate concentrations in leaves and pseudostems during regrowth in a free air carbon dioxide enrichment (FACE) experiment. Plant, Cell and Environment 20: 945-952.
Ganjeali, A. 2012. Effects of foliar application of methanol on growth and root characteristics of chickpea (Cicer arietinum L.) under drought stress. European Journal of Experimental Biology 2: 1697-1702.

Gout, E., S. Aubert, R. Bligny, F. Rébeillé, A.R. Nonomura, A.A. Benson, and R. Douce. 2000. Metabolism of methanol in plant cells: Carbon-13 nuclear magnetic resonance studies. Plant Physiology 123: 287-296.

Hartz, T.K., K.S. Mayberry, M.E. McGiffen, M. LeStrange, G. Miyao, and A. Baameur. 1994. Foliar methanol application ineffective in tomato and melon. HortScience 29: 1087.

Ivanova, E.G., N.V. Doronina, and Y.A. Trotsenko. 2001. Aerobic methylobacteria are capable of synthesizing auxins. Microbiology 70: 392-397.

Karczmarczyk, S., R.M. Devlin, and I.I. Zbiec. 1995. Effect of methanol on winter rape seedlings. Acta Agrobotanica 48: 37-42. (In Polish).

Lee, H.S., M. Madhaiyan, C.W. Kim, S.J. Choi, K.Y. Chung, and T.M. Sa. 2006. Physiological enhancement of early growth of rice seedlings (Oryza sativa L.) by production of phytohormone of $\mathrm{N}_{2}$-fixing methylotrophic isolates. Biology and Fertility of Soils 42: 402-408.

Li, Y., G. Gupta, J.M. Joshi, and A.K. Siyumbano. 1995. Effect of methanol on soybean photosynthesis and chlorophyll. Journal of Plant Nutrition 18(9): 1875-1880.

Madhaiyan, M., S. Poonguzhali, M. Senthilkumar, S. Seshadri, H. Chung, J., Yang, S. Sundaram, and T. S.A. Tongmin. 2004. Growth promotion and induction of systemic resistance in rice cultivar 
Co-47 (Oryza sativa L.) by Methylobacterium spp. Botanical Bulletin- Academia Sinica Taipei 45: 315-324.

Makhdum, M.I., M.N.A. Malik, and S.U. Din, F. Ahmad, and F.I. Chaudhry. 2002. Physiology response of cotton to methanol foliar application. Journal of Researches in Sciences 13: 37-43.

Mauney, J.R., and T.J. Gerik. 1994. Evaluating methanol usage in cotton. p. 39-40. In: Herber, D.J. and D.A. Richter. (eds.). Proc. 1994 Beltwide Cotton Conf., San Diego, Calif., vol. 1. Natl. Cotton Council of Amer., Memphis, Tenn.

McGiffen, M.E., R.L. Green, J.A. Manthey, B.A. Faber, A.J. Downer, N.J. Sakovich, and J. Aguiar. 1995. Field tests of methanol as a crop yield enhancer. HortScience 30: 1225-1228.

Mitchell, A.R., F.J. Crowe, and M.D. Butler. 1994. Plant performance and water use of peppermint treated with methanol and glycine. Journal of Plant Nutrition 17: 1955-1962.

Nadali, I., F. Paknejad, F. Moradi, S. Vazan, M. Tookalo, M. Jami Al-Ahmadi, and A. Pazoki. 2010. Effects of methanol on sugar beet (Beta vulgaris). Australian Journal of Crop Science 4: 398-401.

Nonomura, A.M., and A.A. Benson. 1992. The path of carbon in photosynthesis: Improved crop yields with methanol. Proceedings of the National Academy of Sciences of the United States of America 89: 9794-9798.

Pallardy, S.G. 2010. Physiology of Woody Plants. 3th Ed. Academic Press. 87 pp.

Pourimani, R. and F. Anoosheh. 2015. A study on transfer factors of environmental radionuclides: radionuclide transfer from soil to different varieties of rice in Gorgan, Iran. Iranian Journal of Medical Physics 12: 189-199.

Rajala, A., J. Karkkainen, J. Peltonen, and P. Peltonen-Sainio. 1998. Foliar applications of alcohols failed to enhance growth and yield of $\mathrm{C}_{3}$ crops. Industrial Crops and Products 7: 129-137.

Safarzadeh Vishekaei, M.N., Gh. Normohammadi, E. Majidi-Haravan, and B. Rabiei. 2007. Effect of methanol on growth and yield of peanut (Arachis hypogaea L.). Agricultural Sciences 13: 87104 (In Persian).

Sasaki, T., and B. Burr. 2000. International rice genome sequencing project: The effort to completely sequence the rice genome. Current Opinion in Plant Biology 3:138-141.

Sass, R.L., and R.J. Cicerone. 2002. Photosynthate allocations in rice plants: Food production or atmospheric methane. Proceedings of the National Academy of Sciences of the United States of America 99: 11993-11995.

Theodoridou, A, D. Dörnemann, and K. Kotzabasis. 2002. Light dependent induction of strongly increased microalgal growth by methanol. Biochimica et Biophysica Acta (BBA)-General Subjects 2:189-198.

Wilson, D.R., Yonglin Ding, and S.M. Sinton. 1996. Effects of methanol on growth, water use and yield of barley. Proc. of the 8th Australian Agronomy Conference, Toowoomba.

Zheng, Y.J., Y.Q. Yang, S.S. Liang, and X.F. YI. 2008. Effect of methanol on photosynthesis and chlorophyll fluorescence of flag leaves of winter wheat. Agricultural Sciences in China 7: 432-437. 